\title{
CIVIL RIGHTS OF THE BELIEVERS OF UNOFFICIAL RELIGIONS (PENGHAYAT KEPERCAYAAN) IN PEKALONGAN DISTRICT
}

\author{
Moh. Ilham A Hamudy $\left({ }^{1 *}\right)$, M Saidi Rifki $\left({ }^{2}\right)$ \\ 12 Research and Development Agency, Ministry of Home Affairs, Republic of Indonesia Jakarta, Indonesia.
}

\section{ARTICLE INFORMATION

$\begin{array}{ll}\text { Submitted } & : 20^{\text {th }} \text { November, } 2019 \\ \text { Review } & : 01^{\text {st }} \text { February, } 2020 \\ \text { Accepted } & : 02^{\text {nd }} \text { May, } 2020 \\ \text { Published } & : 1^{\text {st }} \text { June, } 2020 \\ \text { Available Online } & : \text { June, } 2020\end{array}$

\begin{tabular}{lll} 
KEYWORDS & & \\
\hline $\begin{array}{l}\text { Penghayat Kepercayaan; civil rights; } \\
\text { Constitutional Court; local religion; culture; } \\
\text { Pekalongan }\end{array}$ &
\end{tabular}

\section{CORRESPONDENCE}

*E-mail: ilhamhamudy80@gmail.com

\begin{abstract}
A B S T R A C T
There are seven groups of unofficial religions (penghayat kepercayaan) in Pekalongan District. The issuance of Constitutional Court (MK) decision No. 97/ PUU-XIV/2016 did not automatically fulfill their civil rights. There were various obstacles to implement the constitutional court decision. Therefore, this study specifically aimed to review their existence and the fulfillment of their civil rights after the Constitutional Court's decision. With a qualitative approach, and descriptive and literature methods, this study found that the social access of penghayat kepercayaan, such as the inclusion of their beliefs in the religion part of the Identity Card ("KTP"), the availability of penghayat kepercayaan teachers at school, or marriage registration, was yet to be fulfilled. The main obstacles were caused by the inadequate data collection of the penghayat kepercayaan population. Another obstacle was that, although the acceptance of the rest of the community towards the penghayat kepercayaan communities was quite good, the penghayat kepercayaan communities were still concern about them. Past discrimination seems to be main factor. For this reason, responsive works of the Pekalongan District Government are urgently needed to validate the data of penghayat kepercayaan communities and facilitate the social interactions across different communities to nurture a harmonious life in the district.
\end{abstract}

\section{A. INTRODUCTION}

T his study was prompt by the Constitutional Court's ("MK") decision on penghayat kepercayaan in Indonesia. At the end of 2017, the Constitutional Court Panel of Judges issued a decision that the term penghayat kepercayaan can be shown in the religion part of the family card ("KK") and the electronic ID ("KTP") without further specifying it (kompas.com, 2017). The penghayat kepercayaan in this study refers to the community of indigenous religions and beliefs of an ethnic group in Indonesia (a local religion) (Fadli, 2017). They only belief in their ancestor's teachings (Hakiki, 2011; Miharja, 2015; see also Sulaeman et al., 2019).

To a certain extent, members of the penghayat kepercayaan community also prefer to be called penganut kepercayaan. According to them, penghayat means manembah, always self-aware, sincere, patience, and grateful (Habsari, 2018, p. 1), that humans can do nothing, have nothing and have no power whatsoever (Cahyadi, 2018, p. 12).

Decision of the Constitutional Court No. 97/PUU-XIV/2016 granted all the requests for judicial review of Article 61 Paragraphs (1) and (2) as well as Article 64 Paragraphs (1) and (2) of Law No. 24 of 2013 on the Amendments to Law No 23 of 2006 on Population Administration for a proper civil administration. The penghayat kepercayaan communities in Indonesia are not many but they are diverse. 
Based on the 2010 Population Census (SP 2010), the number of penghayat kepercayaan communities are relatively small. There are only 299.617 persons $(0.13 \%)$ of the total population. It was derived from those who choose "others" to answer the question of their religion (program peduli.org, 2018). However, it is quite difficult to have valid numbers of penghayat kepercayaan. In Pekalongan District, referring to the Office of Population and Civil Registration (Dukcapil
Office) of Pekalongan District, on 8 August 2019, there were only 95 persons of penghayat kepercayaan which change their religion status in the KTP, from formerly blank or a dash, into "Kepercayaan terhadap Tuhan YME" (Belief in God). They consist of fifty males and 45 females and spread out in nineteen sub-districts of Pekalongan District. These numbers show the change after the decision of the Constitutional Court No. 97/PUU-XIV/2016.

Table 1.

Number of Penghayat kepercayaan Population

\begin{tabular}{|c|c|c|c|c|}
\hline \multirow{2}{*}{ NO. } & \multirow{2}{*}{ AREAS } & \multicolumn{3}{|c|}{$\begin{array}{c}\text { Type of Belief } \\
\text { ("Kepercayaan") }\end{array}$} \\
\hline & & $\mathbf{M}$ & $\mathbf{F}$ & NUMBER \\
\hline 1 & Kandangserang & 0 & 0 & 0 \\
\hline 2 & Paninggaran & 0 & 0 & 0 \\
\hline 3 & Lebakbarang & 0 & 0 & 0 \\
\hline 4 & Petungkriyono & 0 & 0 & 0 \\
\hline 5 & Talun & 0 & 0 & 0 \\
\hline 6 & Doro & 0 & 0 & 0 \\
\hline 7 & Karanganyar & 2 & 0 & 2 \\
\hline 8 & Kajen & 4 & 2 & 6 \\
\hline 9 & Kesesi & 16 & 14 & 30 \\
\hline 10 & Sragi & 7 & 7 & 14 \\
\hline 11 & Siwalan & 11 & 7 & 18 \\
\hline 12 & Bojong & 2 & 4 & 6 \\
\hline 13 & Wonopringgo & 4 & 6 & 10 \\
\hline 14 & Kedungwuni & 1 & 0 & 1 \\
\hline 15 & Karangdadap & 0 & 0 & 0 \\
\hline 16 & Buaran & 1 & 0 & 1 \\
\hline 17 & Tirto & 0 & 0 & 0 \\
\hline 18 & Wiradesa & 0 & 0 & 0 \\
\hline \multirow[t]{2}{*}{19} & Wonokerto & 2 & 5 & 10 \\
\hline & TOTAL & 50 & 45 & 95 \\
\hline
\end{tabular}

The Dukcapil Office data also shows that they reside in ten sub-districts out of nineteen. Kasesi Sub-district has the most residents (30 persons), followed by Siwalan Sub-district (18 persons), Sragi (17 persons), Wonopringgo (10 persons), Wonokerto ( 7 persons), Kajen and Bojong (6 persons each), Karanganyar (2 persons), Wonopringgo and Kedungwuni (1 person each). The Dukcapil Office data did not show any penghayat kepercayaan in the other nine districts.

This is different from the data from the Office of Education and Culture (Dikbud Office) of Pekalongan District. Data as of May $3^{\text {rd }} 2019$ from Dikbud Office of Pekalongan District showed eight groups of penghayat kepercayaan.
They were: Paguyuban IImu Sejati (46 persons), Paguyuban Ngesti Tunggal (100 persons), Paguyuban Penghayat Kapribaden (544 persons), Paguyuban Tri Tunggal Bayu (60 persons), Paguyuban Kawruh Jawa Jawata (143 persons), Paguyuban Budi Luhur (52 persons), Paguyuban 09 Pambuko Jiwo (50 persons), dan Paguyuban Sapta Dharma (56 persons). Paguyuban Kapribaden has the largest number of members.

However, the data was later revised to only seven groups of Penghayat kepercayaan. Paguyuban Ngesti Tunggal (Pangestu) was declared to be not a part of the Penghayat kepercayaan group since its members are also believers of the six recognized religions. 
Table 2.

List of Penghayat Kepercayaan Groups (May \& August 2018)

\begin{tabular}{|c|c|c|c|c|}
\hline NO. & $\begin{array}{c}\text { NAME OF } \\
\text { PENGHAYAT KEPERCAYAAN } \\
\text { GROUPS }\end{array}$ & ADDRESS & $\begin{array}{l}\text { NAME OF THE } \\
\text { MANAGEMENT/ } \\
\text { PERSON IN } \\
\text { CHARGE }\end{array}$ & $\begin{array}{l}\text { NUMBER OF } \\
\text { MEMBERS }\end{array}$ \\
\hline \multicolumn{5}{|c|}{ MAY 2019} \\
\hline 1 & Paguyuban IImu Sejati & $\begin{array}{l}\text { Jl. Raya Kadipaten No.16 Ds } \\
\text { Kadipaten RT.03/RW.02, Keca- } \\
\text { matan Wiradesa }\end{array}$ & Sumito & 46 \\
\hline 2 & $\begin{array}{l}\text { Paguyuban Ngesti } \\
\text { Tunggal (Pangestu) }\end{array}$ & $\begin{array}{l}\text { Gg Kenangan No } 237 \text { Rejosari, } \\
\text { Bojong }\end{array}$ & Rasmani & 100 \\
\hline 3 & $\begin{array}{l}\text { Paguyuban } \\
\text { Penghayat Kapribaden }\end{array}$ & $\begin{array}{l}\text { Sinangoh Prendeng RT 01/RW 03, } \\
\text { Sinangoh Prendeng, Kajen }\end{array}$ & Sunaryo & 554 \\
\hline 4 & Paguyuban Tri Tunggal Bayu & $\begin{array}{l}\text { Jl Raya Karanganyar, Karangsari, } \\
\text { Karanganyar }\end{array}$ & Sugiharto & 60 \\
\hline 5 & $\begin{array}{l}\text { Paguyuban Kawruh } \\
\text { Jawa Jawata }\end{array}$ & $\begin{array}{l}\text { Sumurjomblang Bogo RT 08/RW 03, } \\
\text { Kecamatan Bojong }\end{array}$ & Sri Renggani & 143 \\
\hline 6 & Paguyuban Budi Luhur & $\begin{array}{l}\text { Babel, RT 17/RW 05, Kecamatan } \\
\text { Wonokerto }\end{array}$ & Suryat & 52 \\
\hline 7 & Paguyuban 09 Pambuko Jiwo & Desa Gebangkerep, Sragi & Sudiyo & 50 \\
\hline 8 & Paguyuban Sapta Dharma & $\begin{array}{l}\text { Desa Wonokerto } \\
\text { Kecamatan Wonokerto }\end{array}$ & Casnari & 56 \\
\hline TOT/ & & & & 1,061 \\
\hline \multicolumn{5}{|c|}{ AUGUST 2019} \\
\hline 1 & Paguyuban Ilmu Sejati & $\begin{array}{l}\text { Jl. Raya Kadipaten No.16 Ds } \\
\text { Kadipaten RT.03/RW.02, Keca- } \\
\text { matan Wiradesa }\end{array}$ & Sumito & 46 \\
\hline 2 & $\begin{array}{l}\text { Paguyuban } \\
\text { Penghayat Kapribaden }\end{array}$ & $\begin{array}{l}\text { Sinangoh Prendeng RT 01/RW 03, } \\
\text { Sinangoh Prendeng, Kajen }\end{array}$ & Sunaryo & 554 \\
\hline 3 & Paguyuban Tri Tunggal Bayu & $\begin{array}{l}\text { Jl Raya Karanganyar, Karangsari, } \\
\text { Karanganyar }\end{array}$ & Sugiharto & 60 \\
\hline 4 & $\begin{array}{l}\text { Paguyuban Kawruh } \\
\text { Jawa Jawata }\end{array}$ & $\begin{array}{l}\text { Sumurjomblang Bogo RT 08/RW 03, } \\
\text { Kecamatan Bojong }\end{array}$ & Sri Renggani & 143 \\
\hline 5 & Paguyuban Budi Luhur & $\begin{array}{l}\text { Babel, RT 17/RW 05, Kecamatan } \\
\text { Wonokerto }\end{array}$ & Suryat & 52 \\
\hline 6 & Paguyuban 09 Pambuko Jiwo & Desa Gebangkerep, Sragi & Sudiyo & 50 \\
\hline 7 & Paguyuban Sapta Dharma & $\begin{array}{l}\text { Desa Wonokerto, } \\
\text { Kecamatan Wonokerto }\end{array}$ & Casnari & 56 \\
\hline \multicolumn{2}{|c|}{ TOTAL } & & & 961 \\
\hline
\end{tabular}

Source: Data from the Dikbud Office of Pekalongan District, 2019

The validity of the data was also debatable. The Dikbud Office data above did not show their distribution across the nineteen sub-districts of Pekalongan District. The Dikbud Office relied on the reports by the representative of the communities in MLKI (Majelis Luhur Kepercayaan Indonesia). According to the Dikbud Office, the number of members may change. It may be more than 1,000 since many individual believers are not registered in any group. For example, the list of members of the Paguyuban Perguruan IImu Sejati shows 165 persons, which were different from the Dikbud Office data (46 persons). The groups also only register members who actively attend routine events held by the group's management.

However, the main issue was not merely about the inconsistency of the numbers of members. It was more about the citizen's equality of rights. The government must serve the citizen equally. The size of the community does not negate that obligation (MK No.97/PUU-XIV/2016, 2017). After the Constitutional Court decision, each of the Penghayat kepercayaan communities would have the first choice to use the name legally. Regardless of the size of the communities, their existence poses a challenge for the 
state to include them in the formal population indicator.

The penghayat kepercayaan communities have never been living a happy life. In the Old Order, they were caught in the political clash between the communist and the religious groups (Magnis-Suseno et al., 2015). Penghayat kepercayaan community's safety is subject to political interest. The Government issued Regulation No 1/PNPS of 1965 on misuse of religion or blasphemy, which further put the penghayat kepercayaan community in a hard spot (Isnur, 2012). After the 1965 Tragedy, the problems continue. Many people accused them to be part of the Indonesian Communist Party (PKI).

Resolution of the People's Consultative Assembly ("TAP MPR") No IV/MPR/1978 on State Policy Guidelines (“GBHN") stated that Kepercayaan was not a religion. This resolution was adopted to accommodate the PPP party, which threatened to walk out from the assembly if penghayat kepercayaan was acknowledged as an equal to religion in the GBHN (geotimes.co.id, 2018). As a result, the life of penghayat kepercayaan in Indonesia continues to be difficult. They keep running into problems in obtaining administration documents (Ginting, 2018). The unfair treatment of the penghayat kepercayaan community is started at school age. In school, they are forced to follow one of the recognized religions for their religious study. While at home, their family educates them to be a penghayat kepercayaan (Aryono, 2018, p. 59). There are various problems they have to deal with in society, such as applying for a job and difficulties to obtain a burial ground in the public cemetery (Sudarto, 2017).

These are the problems that the Constitutional Court responded by declaring that "religion" in Article 61 paragraph (1) and Article 64 paragraph (1) Law No. 23 of 2006 on Population Administration as amendment by Law No. 24 of 2013 on the amendment to Law No, 23 of 2006 is contrary to the 1945 Constitution and does not have a legal force if it does not include aliran kepercayaan (bbc.com, 2017.). The different treatment for the recording of an element of population data is not based on a constitutional reason. The regulation treats the citizen following kepercayaan and the formally recognized religion differently in accessing public service (Aziz Faiz, 2018).

There are multiple studies conducted on the discrimination of treatment by the state to the penghayat kepercayaan communities. A study by Fasya, Ahmad, dan Arifianto (2004) and Fulthoni et al (2009). Sukirno (2018), Colbran (2010), Panjaitan (2018), and Fadli (2017) also conducted a study on discrimination of penghayat kepercayaan by the government. They stated that Indonesia was a failed state in protecting minority rights, and also failed in dealing with intolerance and religious violence. Budijanto (2016), Dwintari (2016), and Adzkiya (2018) also conducted a study on the civil rights of the penghayat kepercayaan community. Generally, the penghayat kepercayaan communities did not have a problem in obtaining services related to population and civil administration. However, there is still discrimination in society such as rejection of funerals, coercion in choosing religious lessons in schools.

Based on the above observation, this study was important and interesting to be conducted since few studies specifically discussed the fulfillment of Civil rights and the existence of the penghayat kepercayaan community after the Constitutional Court decision No.97/PUUXIV/2016, especially in Pekalongan District. This study was aimed to fill the gap. As such, this study discussed (1) how can the penghayat kepercayaan community access the basic social services, and (2) the acceptance of the penghayat kepercayaan community in the Pekalongan District by the society and regional government. This study also showed the penghayat kepercayaan community situation after the Constitutional Court decision No. 97/PUU-XIV/2016, while providing solutions for the fulfillment of civil rights of the communities for an area that still have a problem to fulfill it.

\section{B. METHOD}

$\mathrm{T}$ his study combined descriptive methods and document analysis. The descriptive method was intended to describe the civil rights of penghayat kepercayaan as a unit of analysis after the Constitutional Court decision based on facts as they were presented (Sugiyono, 2015). The desktop study method 
was intended to gather relevant information on the existence of the penghayat kepercayaan community in Pekalongan District. This information was obtained through reviewing books, scientific works, thesis, dissertations, encyclopedias, internet, and other sources (Zed, 2004). This study used interview techniques to gather the relevant data, collecting information from the chairmen and the members of the penghayat kepercayaan groups in Pekalongan District that were purposely selected.

The approach used in this study was the qualitative approach. This approach was appropriate since the existence of penghayat kepercayaan was considered to be multidimensional (Alwasilah, 2003). Meanwhile, the collection of facts and data was done by tracing the news in mainstream mass media to enrich the analysis. This study was carried out between early June 2019 to end of August 2019.

\section{RESULTS AND DISCUSSION}

$\mathrm{n}$ this part, the answer to the study questions regarding (1) social access of penghayat kepercayaan, and (2) social acceptance of the surrounding communities are discussed:

\section{Social Access}

The basic services, especially the civil administration services, provided by the Pekalongan District government to the penghayat kepercayaan communities, are quite well. However, it was not sufficient since there are still some rights that they can't access. The Government's inability to provide access to education for the children of penghayat kepercayaan indicates the government's lack of attention to that right. The lack of valid data on the number of penghayat kepercayaan population in Pekalongan District also shows that the government was not striving to make minority groups as legal subjects that have the same rights and opportunities as other citizens. he Constitutional Court decision No. 97/PUUXIV/2016 granted all the requests for judicial review of Article 61 Paragraphs (1) and (2) as well as Article 64 Paragraphs (1) and (2) of Law No. 24 of 2013 on the Amendments to Law No 23 of 2006 on Population Administration. The government did not directly socialize the decision to the penghayat kepercayaan communities. The socialization Regulation No. 40 of 2009 on Population Administration relating to marriage administration for the penghayat kepercayaan community members that have not adopted one of the recognized religions, was also not conducted.

The Chairman and Secretary of Penghayat Kapribaden Community also confirm that many of them are not counted yet. According to him, the number of his community should be around 500 persons. Some people subscribe to Penghayat Kapribaden's beliefs but not registered in his group. In one sub-district, the number of Penghayat Kapribaden may reach 50 persons. Karanganyar Sub-district might have $70-80$ persons of penghayat Kapribaden, while Kasesi Sub-district might have $30-50$ persons. The same situation also described by the Chairman of Paguyuban Tri Tunggal Bayu (TTB). The Chairman stated that the numbers of the TTB community might be in thousands if the sympathizers were counted as their members. The Dikbud Office's data only shows those who formally recognized as TTB followers. The sympathizers, those who formally belong to one of the recognized religions but were interested in the TTB teachings, were not counted.

The socialization of the regulations by the Dukcapil Office currently only targeting the chairmen of the penghayat kepercayaan groups and not conducted directly to the communities. $\mathrm{He}$ believed that the regulation was known by the chairmen of the groups, and the chairmen might convey the regulation to their people. The leaders of the penghayat kepercayaan groups often represent their community members to change their religion status in the Dukcapil Office, showing a statement letter from the leader of the penghayat kepercayaan community or the chairman of the group.

\section{a. Other Population Administration Services}

Aside from the religion part of the KTP, other population administration services that showed inaccurate data were marriage and death of the penghayat kepercayaan. After the issuance of the new regulation, data form the Dukcapil Office did not show any record of penghayat kepercayaan marriage. This was acknowledged by the Head of Population Registration Unit and the Head of Birth Registration Section of 
Pekalongan District. Based on the Dukcapil Office data, as of Trimester $11 / 2018$, the population of Pekalongan District is 944,398 persons, and approximately $7 \%$ are non-Moslem. Based on the population report of the Pekalongan District in the same year, the penghayat kepercayaan population was only 45 persons $(23$ males and 22 females). This means that only
$0.00 \%$ of the total population was registered in the Dukcapil Office. In 2018, the Dukcapil Office recorded 25 non-Moslem marriage and no penghayat kepercayaan marriage. The data on the death of penghayat kepercayaan community was also not available due to society's lack of understanding regarding this matter.

Table 3.

Population report (per type of religion) in the Districts/Cities

\begin{tabular}{ccccc}
\hline RELIGION & MALE & FEMALE & Total & $\%$ \\
\hline Islam & 476,675 & 463,705 & 940,380 & $99.57 \%$ \\
\hline Protestant & 1,233 & 1,262 & 2,495 & $0.26 \%$ \\
\hline Catholic & 470 & 491 & 961 & $0.10 \%$ \\
\hline Hindu & 216 & 185 & 401 & $0.04 \%$ \\
\hline Buddha & 58 & 48 & 106 & $0.01 \%$ \\
\hline Confucius & 5 & 5 & 10 & $0.00 \%$ \\
\hline Kepercayaan & 23 & 22 & 45 & $0.00 \%$ \\
\hline Total & \multicolumn{3}{c}{944,398} & $100.00 \%$ \\
\hline Source: Data from the Dukcapil Office of Pekalongan District, $11 / 2018$
\end{tabular}

Table 4.

Deeds issued by the Dukcapil Office of Pekalongan District, 2018

\begin{tabular}{|c|c|c|c|c|c|c|c|c|c|c|}
\hline NO & MONTH & BIRTH & $\begin{array}{l}\text { 2ND } \\
\text { COPY }\end{array}$ & $\begin{array}{l}\text { MARRIAGE } \\
\text { CERTIFICATE }\end{array}$ & DIVORCE & DEATH & $\begin{array}{l}\text { CHANGE } \\
\text { OF } \\
\text { NAME }\end{array}$ & $\begin{array}{l}\text { ACKNOWLE } \\
\text { DGMENT } \\
\text { OF A CHILD }\end{array}$ & ADOPTION & TOTAL \\
\hline 1 & Jan & 2,260 & 47 & 2 & 0 & 195 & 0 & 0 & 2 & 2,506 \\
\hline 2 & Feb & 2,030 & 73 & 3 & 0 & 34 & 3 & 0 & 0 & 2,143 \\
\hline 3 & Mar & 1,984 & 54 & 0 & 0 & 173 & 1 & 0 & 1 & 2,213 \\
\hline 4 & Apr & 2,145 & 51 & 5 & 0 & 59 & 0 & 1 & 0 & 2,261 \\
\hline 5 & May & 2,208 & 73 & 1 & 0 & 209 & 1 & 1 & 3 & 2,496 \\
\hline 6 & June & 1,011 & 34 & 1 & 0 & 42 & 0 & 0 & 1 & 1,089 \\
\hline 7 & July & 3,195 & 152 & 2 & 0 & 23 & 2 & 0 & 0 & 3,374 \\
\hline 8 & Aug & 2,493 & 121 & 3 & 0 & 138 & 3 & 0 & 1 & 2,759 \\
\hline 9 & Sept & 2,304 & 102 & 2 & 0 & 31 & 1 & 0 & 0 & 2,440 \\
\hline 10 & Oct & 2,336 & 198 & 2 & 1 & 28 & 7 & 0 & 0 & 2,572 \\
\hline 11 & Nov & 2,325 & 114 & 1 & 1 & 43 & 6 & 0 & 1 & 2,491 \\
\hline 12 & Dec & 2,354 & 169 & 3 & 0 & 28 & 3 & 0 & 0 & 2,557 \\
\hline \multicolumn{2}{|c|}{ TOTAL } & 26,645 & 1,188 & 25 & 2 & 1,003 & 27 & 2 & 9 & 28,901 \\
\hline
\end{tabular}

There are some reasons why the penghayat kepercayaan marriage was not conducted. One of them was that, legally, a marriage should be conducted based on the religion notation in the couple's KTP, while most of the members refused to change the notation in the religion part of the KTP to state penghayat kepercayaan. The process to issue the marriage certificate was also very long. (Susetyo, 2017, p. 149). The penghayat kepercayaan members must change 
the notation in the religion part of their KTP first. Government Regulation No. 40 of 2019 states that the recording of marriages of penghayat kepercayaan is carried out at the District/City Dukcapil Office or the District/City Population and Civil Registration Work Unit at the latest 60 days after the marriage held before their leaders.

Changing the notation in the religion part of the KTP was also not easy (Kurniawan, 2015). The process was long, and the community's will to change it was lacking. This fact was also acknowledged by the Chairman of Paguyuban Penghayat Kapribaden Tri Tunggah Bayu, who stated that besides being lazy due to the length of time it took to process one, they also consider processing population documents as complicated. he long length of time a KTP issuance was also acknowledged by the Pekalongan District Population and Civil Registration Office. They complained about the lack of KTP forms. (see also Ansyari, Amin, \& Resmawan, 2018).

At the time of the study, the socialization of the new regulation was carried out by the central government. The Pekalongan District government rarely pro-actively socialize it. The socialization by the central government also was not properly conducted. The socialization by the central government also was not properly conducted. The regional government in charge of population administration was never invited to the socialization events. The officers only invited the chairmen of the penghayat kepercayaan groups. The old chairmen would not be able to socialize the new regulation across the nineteen sub-districts in Pekalongan District. Without the socialization of the new regulations, the members of penghayat kepercayaan will still be an outcast, and discrimination views about them would still be nurtured.

\section{b. Access to Education}

The Head of Culture and the Head of History \& Muskala Section of the Dikbud Office of Pekalongan District stated that there were 500 elementary schools, 78 junior high schools, and 37 high schools in Pekalongan District. The Dikbud Office did not have data on the penghayat kepercayaan students in those schools. They did not receive any reports, either from the penghayat kepercayaan communities or the schools.
He stated that they were ready to provide the teachers for the students if they receive the reports and data on penghayat kepercayaan students. The Dikbud Office acknowledged the likelihood of penghayat kepercayaan students in their schools.

The difficulty of finding penghayat kepercayaan students in SMPN 01 Bojong was due to a lack of synchronization between the student's main data and other available data, such as the Guidance Counseling teacher's data. The main student data stated that all students in SMP 01 are Moslem. The new headmaster also did not receive any information on penghayat kepercayaan students from the teachers, the students, or their parents.

The student stated that the student informed the previous headmaster of the student's beliefs. However, there was no special teacher to teach the penghayat kepercayaan study. The student attended the Islamic study with the Moslem classmates, which the student could still accept. The student also stated that there is another penghayat kepercayaanstudent in another school, SMPN 02 Bojong.

We did not find any student with a penghayat kepercayaan background in SDN 01 and SDN 02 Sinagoh Prendeng, Kajen. Data from both schools stated that $100 \%$ of students are Moslems, in line with the student's parents' KTP. This data is quite odd since Sinangoh Prendeng is possibly a village with the largest number of penghayat kepercayaan. The village has a ritual ceremony and is a gathering place of the Paguyuban Kapribaden. The headmaster knew that there were a number of the students' parents who subscribed to penghayat kepercayaan, but they still register their children as Moslems. The headmaster of SDN 01 and SDN 02 also said there were no reports from students' parents on the existence of penghayat kepercayaan students. The Dikbud Office acknowledged that they did not pro-actively verify the existence of penghayat kepercayaan students. However, socializations were carried out to school headmasters to update and report if they found penghayat kepercayaan students.

The government gave a choice to the penghayat kepercayaan believers, not to attend religious studies in formal schools (Wahyudi, 2018) because Pekalongan District did not have a special teacher for penghayat kepercayaan. 
However, one of Pekalongan District resident is a counselor for penghayat kepercayaan study, but he teaches in Batang District, at SMP 3 Warung Asem and SD Pejambon. Pagulno, the teacher, manages Paguyuban Kawruh Jawa Jawata. He also serves as an educational counselor in several schools for penghayat kepercayaan students. As a counselor, he has an official certificate from BNSP (National Professional Certification Agency).

Several factors cause the penghayat kepercayaan children in Pekalongan District to fail to receive the penghayat kepercayaan study in their school. One of the reasons was that the government failed to collect data on penghayat kepercayaan students. The socialization of Minister of Education and Culture Regulation No. 27 of 2016 on Penghayat kepercayaan Education Services is also not comprehensive. The regulation seemed to be issued in a hurry. As a result, the teaching kit is incomplete, as acknowledged by the Headmaster of SMPN 01 Bojong.

The regulation was new and rather difficult to implement. The affected students were familiar with the general subjects. There was a concern that the students would be confused with the penghayat kepercayaan study. For example, they worried that their classmates might treat them differently. They also worried that they might be discriminated against by their classmates and teachers. Not to mention the stigma from the community that views the penghayat kepercayaan as an atheist and have no religion. Another difficulty was because the schools require them to choose to learn the teachings of other religions so they can graduate (compare with Haryadi, Salfutra, \& Darwance, 2018).

At the time of the study, there was no demand from the schools for penghayat kepercayaan teachers. The local government was waiting for information from the schools and the penghayat kepercayaan communities. There was no coordination on the supply of penghayat kepercayaan teachers in the Pekalongan District. The schools, the government, and the penghayat kepercayaan community were waiting for each other to make the first move. The MLKI, as the coordinator of all penghayat kepercayaan groups in Pekalongan District, did not inform the 55 | P a g e

https://doi.org/10.25077/jantro.v22.n1.p48-59.2020 government on the existence of penghayat kepercayaan students in the school.

The absence of a penghayat kepercayaan teacher was not without reason. There are no teachers who have a suitable diploma to teach that subject.The Pekalongan District Government is not seriously recruiting penghayat kepercayaan counselors. There were a lot of interests in the community to be a penghayat kepercayaan counselor. However, if everything depends on the penghayat kepercayaan group, it will be impossible since it will require a large number of funds. But the Pekalongan District Dikbud Office denied this information. According to the Office, the government allocated funds for instructors or teachers. The Dikbud Office regretted that the penghayat kepercayaan counselor was active outside the Pekalongan District.

Valid data related to the number of penghayat kepercayaan believers is quite important. With such data, it will be easier for the government to fulfill their civil rights, such as health services, social assistance, or access to education. Valid data will also minimize the non-fulfillment of student services in schools or dismissal of teachers such as those in Brebes (Royani, 2014) Semarang, (Aziz, 2016), Garut (Erdianto, 2017; Wahyu, 2019) and other cities.

Nonfulfillment of services/civil rights will not happen if the government facilitates the teaching for students according to their respective beliefs. However, if religious studies in schools are abolished, it would be better because the religious study made the students to be segregated. For example, for an Islamic study, the students of other faiths must leave the classroom.

The teaching of manners should be more important in school, while the teaching of religion should be conducted by their parents (Lubis, 2019; Suwardi, 2010). Religious study in several countries, such as Finland and Greece, contains the teaching of cultural identity, character, tolerance, and having a constructive and critical approach (Kallioniemi \& Ubani, 2016; Koukounaras Liagkis, 2015).

The absence of penghayat kepercayaan study in schools was caused by the recognition of the six official religions in 1968, which then changed the community's view against local religious groups They assumed that penghayat keper-

MOH. ILHAM A HAMUDY, M. SAIDI RIFKI 
cayaan was not equal to the six religions. Initially, the government intended to formalize the religion of migrants, while penghayat kepercayaan as the original religion of the archipelago did not need further recognition by the government.

\section{Social Acceptance of the Society}

A large number of students who register as Moslems in several schools was because the religion column has not been changed in their parents' ID card and Family Card. The community members who stated one of the recognized religions on their KTPs were reluctant to register their children as a penghayat kepercayaan in school, as in SDN 01 and 02 Sinangoh Prendeng. Sinangoh Prendeng Village was mentioned as an area with the most penghayat kepercayaan population in Kajen.

The residents' reluctance to change their religion status was due to their past trauma. Many of them were summoned by the authority, cast aside, and suffered other discriminatory acts. As such, some of them still feel insecure to admit that they are penghayat kepercayaan followers (Sulaiman, 2018). Some of them, mainly those who reside in villages, would maintain their distance. Some who keep a different appearance, such as not wearing a headscarf, was afraid that they would be labeled kafir (non-believer) or munafiq (hypocrites), although the Pekalongan Districts seem to be quite tolerant and there were no issues with any religious followers.

It seems that the main factor of not stating their true beliefs in their KTP is from their view of the environment. This belief resulted in difficulty to obtain the real number of penghayat kepercayaan (Hamali, 2012). Their view of their environment also causing the decrease of penghayat kepercayaan throughout the years. According to one of the chairmen of the penghayat kepercayaan group, many of their members stated Islam as their religion because they were listed as the mosque caretaker in their neighborhood. Also, many of them married people that subscribe to one of the recognized religions, and they elect to adopt their spouse's religion as their own.

It took lots of courage for penghayat kepercayaan to show their real beliefs (Budijanto, 2016). At the time of the study, approximately $1 \%$ of them have had the courage to keep the religion part of their KTP empty or to change it. The small Paguyuban Kapribaden also has the same situation. Even its Secretary refused to change the religion part of his KTP. His reason was that even his KTP stated his religion is Islam, he and his family were able to conduct their daily life according to the community's traditions. Another problem is that the government seems to be reluctant to change people's opinions on the difficulties of arranging population administration documents. This situation happened in both the education sector and civil registration (NFID, 2019). Although the Constitutional Court decision is final, many of the penghayat kepercayaan are not so keen on changing their religion part of their KTP, because they know that they would encounter problems when they deal with local government.

As such, many population records are not valid. For example, the different record of religion in their family card (KK) and KTP. Their KK stated that they are penghayat kepercayaan, but their KTP stated Islam. The penghayat kepercayaan community also think that they would have problems with the village officers to obtain their population documents. It is a concern since the old penghayat kepercayaan seems to be no longer care with population documents such as KTP.

Another concern prior to the issuance of GR No 40 of 2019 on Population Administration is on the marriage of penghayat kepercayaan (Ridha, Sukirno, \& Sudaryatmi, 2017). The marriage procedures in Pekalongan District were still based on the six recognized religions. The Dukcapil Office was only willing to record and provide a copy of the marriage certificate when all requirements were met, one of them is the availability of the guardian for the bride and groom (their parents). While under the penghayat kepercayaan belief, there is no need for such a guardian. According to their beliefs, the parents are not their guardian. The parents are there to witness and bless the marriage of their children.

\section{CONCLUSIONS}

$\mathrm{T}$ he Constitutional Court's decision has placed the penghayat kepercayaan to be equal to the existing religions in Indonesia. The Constitutional Court's decision has placed the penghayat kepercayaan to be equal to the 
existing religions in Indonesia. It means that there will be many regulations that need to be adjusted to the Constitutional Court's Decision. Including regulations to ensure their civil rights to have their places of worship, having their marriage rituals, having education according to their beliefs, and others are fulfilled.

In terms of the availability of government regulation, there was no significant gap to fulfill the civil rights of the penghayat kepercayaan community in the Pekalongan District. The existing regulation already accommodates their needs. The problems are mostly in implementing it. The regional government was not responsive enough to adjust to the Constitutional Court decision No 97/PUU-XIV/2016. The regional government was slow in fulfilling the civil rights of the penghayat kepercayaan communities. The regional government should be proactive in registering the penghayat kepercayaan communitiesin Pekalongan District.

With valid data, the regional government can determine the numbers of the penghayat kepercayaan in Pekalongan District. The government can use this data to determine resource allocation (personnel or budget) to serve the penghayat kepercayaan communities. This is the role of the Dukcapil Office. The valid data would then be used by Bappeda Pekalongan District to determine the budget allocated to the work units in the area. The regional employment unit also can allocate the necessary personnel, especially teachers, for schools that have penghayat kepercayaan students.

The participation of penghayat kepercayaan communities is needed. Their pro-active involvement in providing data, showing their existence, and socializing with the majority is a necessity to form a harmonious relationship amongst various community members.

\section{E. ACKNOWLEDGMENT}

W e would like to thank the Pekalongan District government for their generosity in funding this study. Especially to the Regional Research and Development Planning Agency, the Dukcapil Office, the Office of Education and Culture, and the Chairmen of the Penghayat kepercayaan Groups in Pekalongan Regency who have helped us immensely in collecting data.

\section{REFERENCES}

Adzkiya', U. (2018). Pemenuhan Pendidikan Keagamaan Bagi Penghayat Kepercayaan (Studi Kasus Di Komunitas Sedulur Sikep Kab. Kudus) [Magister Manajemen Pendidikan Program Pascasarjana FKIP-UKSW].

Alwasilah, A. C. (2003). Pokoknya Kualitatif: Dasar-Dasar Merancang dan Melakukan Penelitian Kualitatif. Pustaka Jaya.

Ansyari, F., Amin, J., \& Resmawan, E. (2018). Analisis Standar Pelayanan Pembuatan E-Ktp di Dinas Kependudukan dan Catatan Sipil Kabupaten Paser. EJournal Administrative Reform, 6(3), 301312.

Aryono, A. (2018). Pergulatan Aliran Kepercayaan dalam Panggung Politik Indonesia, 1950an2010an: Romo Semono Sastrodihardjo dan Aliran Kapribaden. Jurnal Sejarah Citra Lekha, 3(1), 58. https://doi.org/10.14710/jscl.v3i1.17855

Aziz, A. (2016). Diskriminasi Penganut Kepercayaan. Tirto.ld.

Aziz Faiz, A. (2018). Kebijakan Negara dalam Mengakomodir Agama Pribumi Perspektif SosialAntropologi. Jurnal Pemberdayaan Masyarakat: Media Pemikiran Dan Dakwah Pembangunan, 2(2), 211-226. https://doi.org/10.14421/jpm.2018.022-01

bbc.com. (2017). Putusan MK "angin segar" dan "memulihkan martabat" penghayat kepercayaan. BBC News Indonesia.

Budijanto, O. W. (2016). Penghormatan Hak Asasi Manusia Bagi Penghayat Kepercayaan di Kota Bandung. Hak Asasi Manusia, 7(1).

Cahyadi, W. (2018). Karya Musik "Ngragi.” Dewa Ruci: Jurnal Pengkajian Dan Penciptaan Seni, 13(1), $11-20$. 
Colbran, N. (2010). Realities and challenges in realising freedom of religion or belief in Indonesia. The International Journal of Human Rights, 14(5), 678-704. https://doi.org/10.1080/13642980903155166

Dwintari, J. W. (2016). Kesetaraan Hak Memperoleh Pendidikan Kepercayaan Bagi Penghayat Kepercayaan [Universitas Sebelas Maret].

Erdianto, K. (2017). Mendikbud Larang Sekolah Mendiskriminasi Siswa Penghayat Kepercayaan. Kompas.Com.

Fadli, M. (2017). Constitutional Recognition and Legal Protection for Local Religion in Indonesia: A Discourse on Local Religion of the Tengger and Baduy People. Pertanika Journals Social Science \& Humanities, 25(2). https://doi.org/10.1016/0042-6989(95)00038-2

Fasya, A. 'Aunillah, Ahmad, A. A. H., Arifianto, M. L., \& Zainurrakhmah. (2004). The Dynamics of Relation between the State and Local Religions in Indonesia: Between Idealism and Reality. AlAlbab, 4(2), 215-261.

Fulthoni, Arianingtyas, R., Aminah, S., \& Sihombing, U. P. (2009). Memahami Diskriminasi; Buku Saku untuk Kebebasan Beragama. The Indonesian Legal Resource Center (ILRC).

geotimes.co.id. (2018). Memberi Keadilan bagi Penghayat. Geotimes.Co.Id.

Habsari, N. T. (2018). Adam Religion in the Religious Life of Samin Tribe in Sumberbening Village Ngawi 1969-1999. Jurnal Antropologi: Isu-Isu Sosial Budaya, 19(2), 155. https://doi.org/10.25077/jaisb.v19.n2.p155-165.2017

Hakiki, K. M. (2011). Politik Identitas Agama Lokal (Studi Kasus Aliran Kebatinan). Analisis: Jurnal Studi Keislaman, 11(1), 159-174. https://doi.org/10.24042/AJSK.V1111.617

Hamali, S. (2012). Dampak Konversi Agama terhadap Sikap dan Tingkah Laku Keagamaan Individu. Al-Adyan: Jurnal Studi Lintas Agama, 7(2), 21-40. https://doi.org/10.24042/AJSLA.V7I2.503

Haryadi, D., Salfutra, R. D., \& Darwance. (2018). Implementasi Putusan Mahkamah Konstitusi Nomor 97/PUU-XIV/2016 tentang Pengujian Undang-Undang Administrasi Kependudukan Terhadap Penghayat Kepercayaan Orang Lom Suku Mapur di Kepulauan Bangka Belitung.

icjr.or.id. (2012). Mengenal Kovenan Internasional Hak Sipil dan Politik. Icjr.or.Id.

Isnur, M. (2012). Agama, Negara, dan Hak Asasi Manusia: Proses Pengujian UU 1/PNPS/1965 Tentang Pencegahan, Penyalahgunaan, Dan/atau Pengodaan Agama di Mahkamah Konstitusi. LBH Jakarta.

Kallioniemi, A., \& Ubani, M. (2016). Religious Education in Finnish School System. In Miracle of Education. Brill | Sense. https://doi.org/10.1163/9789460918117_013

kompas.com. (2017). MK: Kolom Agama di KTP dan KK Dapat Ditulis \&quot;Penghayat Kepercayaan\&quot; Kompas.Com.

Koukounaras Liagkis, M. (2015). Religious Education in Greece: a New Curriculum, an Old Issue. British Journal of Religious Education, 37(2), 153-169. https://doi.org/10.1080/01416200.2014.944093

Kurniawan, I. (2015). Memerangi Diskriminasi Atas Minoritas. Kabar Kampoeng.

Lubis, S. (2019). Tinjauan Normatif Kurikulum Pendidikan Agama Islam Dalam Penanaman Nilai-Nilai Anti-Korupsi. Murabbi : Jurnal IImiah Dalam Bidang Pendidikan, 02(01), 31-47.

Magnis-Suseno, F., Sumaktoyo, S. N. G., Kolimon, M., Pasiak, T., Wahid, A., Mufid, A. S., Imanulhaq, M., \& Sciortino, R. (2015). Agama, Keterbukaan dan Demokrasi Harapan dan Tantangan (Cetakan 1). Yayasan Paramadina.

Miharja, D. (2015). Sistem Kepercayaan Awal Masyarakat Sunda. Al-Adyan, 10(1), 19-36.

NFID. (2019). Kelompok Warga Rentan dalam Tujuan Pembangunan Berkelanjutan; ak Satupun Kelompok Rentan Tertinggal: Korban Pelanggaran HAM Masa Lalu, Masyarakat Adat, serta Minoritas Agama dan Keyakinan.

Panjaitan, A. K. (2018). Implikasi Pengosongan Kolom Agama dalam Kartu Tanda Penduduk Terhadap Pemenuhan Hak Konstitusional Umat Baha'i. Indonesian State Law Review, 1(1), 116.

programpeduli.org. (2018). Keadilan bagi Penghayat Kepercayaan. Programpeduli.Org. 
Royani, Y. M. (2014). Problem Penghayat Kepercayaan di Jawa Tengah: Catatan untuk Tahun 2013. Elsaonline.Com.

Sudarto. (2017). Kondisi Pemenuhan Hak KonstitusionaL Penghayat Kepercayaan Terhadap Tuhan Yang Maha Esa.

Sugiyono. (2015). Metode Penelitian Kuantitatif, Kualitatif dan R\&D (Qualitative and Quantitative Research Methods). Alfabeta.

Sukirno, S. (2018). Diskriminasi Pemenuhan Hak Sipil Bagi Penganut Agama Lokal. Administrative Law \& Governance Journal, 1(3), 231-239.

Sulaeman, S., Malawat, M., \& Darma, D. (2019). Konstruksi Makna Bakupukul Manyapu bagi Masyarakat Mamala Maluku. Jurnal Antropologi: Isu-Isu Sosial Budaya, 21(1), 61. https://doi.org/10.25077/jantro.v21.n1.p61-72.2019

Sulaiman, S. (2018). Problem Pelayanan terhadap Kelompok Penghayat Kepercayaan di Pati, Jawa Tengah. Jurnal SMART (Studi Masyarakat, Religi, Dan Tradisi), 4(2), 207-220. https://doi.org/10.18784/smart.v4i2.649

Susetyo, H. (2017). Pencatatan Perkawinan bagi Golongan Penghayat. Jurnal Hukum \& Pembangunan, 28(1-3), 149. https://doi.org/10.21143/jhp.vol28.no1-3.542

Suwardi. (2010). Etika Kebijaksanaan dalam Ajaran Budi Pekerti Luhur Penghayat Kepercayaan Kejawen. Makara, Sosial Humaniora, 14(1), 1-10.

Wahyu, D. N. (2019). Pendidikan Anak Penghayat Kepercayaan di SMA 9 dan SMP 59 Surabaya [UIN Sunan Ample].

Wahyudi, M. (2018). Analisis Masuknya Aliran Kepercayaan di Kolom Agama dalam Kartu Keluarga dan Kartu Tanda Penduduk; (Studi Putusan Mahkamah Konstitusi Nomor 97/PUU-XIV/2016 tentang Yudicial Review Undang-Undang Administrasi Kependudukan) [Magister IImu Hukum].

Zed, M. (2004). Metode Penelitian Kepustakaan. Yayasan Pustaka Obor Indonesia. 